\title{
Exchangeable potassium reserve in a Brazilian savanna Oxisol after nine years under
}

\section{different cotton production systems}

\author{
Alexandre Cunha de Barcellos Ferreira ${ }^{*} \oplus$, Ana Luiza Dias Coelho Borin ${ }^{1}$, Fernando Mendes Lamas ${ }^{2} \odot$, Gilvan Barbosa Ferreira ${ }^{1}$, \\ Álvaro Vilela de Resende ${ }^{3 \oplus}$
}

${ }^{1}$ Embrapa Algodão, R. Oswaldo Cruz, 1143 - 58428-095 Campina Grande, PB - Brasil.

${ }^{2}$ Embrapa Agropecuária Oeste, Rod. BR163, km 253,6, C.P. 449 - 79804-970 - Dourados, MS - Brasil.

${ }^{3}$ Embrapa Milho e Sorgo, Rod. MG424, km 45, C.P. 285 -

35701-970 - Sete Lagoas, MG - Brasil.

${ }^{*}$ Corresponding author <alexandre-cunha.ferreira@embrapa.br>

Edited by: Tiago Osório Ferreira

Received October 28, 2020

Accepted April 13, 2021
ABSTRACT: Adequate potassium (K) fertilization is essential for agricultural production in soils of the Brazilian Savanna (Cerrado biome) due to the high demand by crops (especially cotton), likelihood of leaching losses, and the dependence on fertilizer importations. Therefore, sustainability requires improvements in the soil efficiency management. This study evaluated the influence of soil management and crop succession or rotation combinations with cotton on $\mathrm{K}$ dynamics and exchangeable reserves in the soil profile, and the partial balance of $\mathrm{K}$ after nine years of cultivation in a clayey Oxisol in the Cerrado. The soil was sampled in layers up to $100 \mathrm{~cm}$ depth in four cotton production systems treatments: 1) conventional soil tillage (CST) with cotton monoculture; 2) CST with annual cotton-soybean-cotton succession; 3) CST with cotton/soybean/maize rotation; and 4) no-tillage system (NTS) with cotton/soybean/ maize rotation and Urochloa ruziziensis (ruzigrass) as a cover crop in the off-season after grain crops. The experiment was conducted using a randomized block design with four replications. CST with cotton monoculture favored the leaching of $\mathrm{K}$ surplus from fertilization. Crop rotation including ruzigrass in the NTS allowed better control of $\mathrm{K}$ dynamics, ensuring its circulation in the soil-plant compartments and reducing leaching. The increased organic matter (OM) in this system enlarges the storage capacity of $\mathrm{K}$ in the topsoil. The adoption of no-tillage crop systems integrating ruzigrass is viable to improve the efficiency of $\mathrm{K}$ fertilizers in cotton cultivation in highly weathered tropical soils.

Keywords: Urochloa ruziziensis, no-tillage, long-term experiment, potassium fertilization, tropical savanna

\section{Introduction}

Brazil is one of the world's major cotton producers with a cultivated area of 1.66 million ha in the 2019-2020 season and $98 \%$ of the production from the Cerrado biome $(\mathrm{CONAB}, 2020)$, a Brazilian tropical savanna that encompasses around 205 million ha. Oxisols (Soil Survey Staff, 2014), predominant soil group in the Cerrado, have good drainage, but are naturally acidic, presenting high $\mathrm{Al}$ saturation and poor natural fertility with low OM content and CEC. The use of liming and fertilizer amendments in the last decades led soils to become one of the most relevant agricultural environments for food production worldwide (Lopes and Guilherme, 2016).

To achieve high yield and fiber quality, cotton cropping in Cerrado uses large amounts of fertilizers, which increase the production cost. Cotton demands high amounts of $\mathrm{K}$, since it is vital for fiber formation and quality (Yang et al., 2016). The production of 1 ton of seed cotton requires an extraction equivalent to 58 $\mathrm{kg} \mathrm{ha}^{-1}$ of $\mathrm{K}_{2} \mathrm{O}$ from the soil, but only $30 \%$ of that is exported by the harvested cottonseeds and fibers (Borin et al., 2019).

In tropical soils, $\mathrm{K}$ supply to plants occurs mainly by the exchangeable form, but also by the non-exchangeable form and $\mathrm{K}$ is also released by crop residues (Rosolem et al., 2019). Depending on fertilizer management, crop combination, and soil characteristics, $\mathrm{K}$ surplus from fertilization remain more susceptible to runoff or leaching losses. Since these soils have a limited $\mathrm{K}$ adsorption capacity, no-tillage system (NTS) and the insertion of forage grasses into crop rotation can be a strategy to conserve soil K fertility, because Poaceae plants are very efficient in cycling K (Garcia et al., 2008; Resende et al., 2019; Rosolem et al., 2019).

Consumption of $\mathrm{K}$ fertilizers in Brazil reached 6.77 million tons of $\mathrm{K}_{2} \mathrm{O}$ in 2018, while worldwide use corresponded to 38.85 million tons of $\mathrm{K}_{2} \mathrm{O}$ (FAO, 2020). National mineral reserves are limited and currently about $95 \%$ of the $\mathrm{K}$ fertilizer is imported (Boldrin et al., 2019), which justifies efforts in developing technical approaches to increase the $\mathrm{K}$ use efficiency in the Brazilian agriculture.

This study evaluated the influence of soil management and crop combinations with cotton on $\mathrm{K}$ dynamics, exchangeable reserves in the soil and partial balance after nine years in a clayey Oxisol in the Brazilian Cerrado.

\section{Materials and Methods}

\section{Study site}

A long-term experiment under rainfed conditions was conducted between Aug 2005 and Oct 2014 in the 
municipality of Santa Helena de Goiás, Goiás, Brazil (17 ${ }^{\circ} 50^{\prime} 37^{\prime \prime} \mathrm{S}, 50^{\circ} 35^{\prime} 52^{\prime \prime} \mathrm{W}$, and altitude $557 \mathrm{~m}$ ). The soil is classified as clayey dystrophic Red Latosol (Santos et al., 2013), Typic Haplorthox (Oxisol) (Soil Survey Staff, 2014). The climate is Aw, according to the Köppen-Geiger climate classification system (Alvares et al., 2013), with an average rainfall of $1,800 \mathrm{~mm}$, concentrated from Oct to Mar.

In the three years prior to the experiment, the area was cultivated with cotton, and before that, soybean monoculture, with the soil prepared annually by plowing and harrowing. In Aug 2005, the soil was sampled at $0-20 \mathrm{~cm}$ depth and underwent the chemical and particle size analyses (Table 1). In early Sept 2005, the entire experimental area received $2,200 \mathrm{~kg} \mathrm{ha}^{-1}$ of calcitic limestone with $90 \%$ calcium carbonate equivalent and was subsoiled at $35 \mathrm{~cm}$ depth, subsequently plowed and harrowed.

\section{Experimental design and treatments}

The experiment was conducted for nine years and consisted of four production systems involving cotton cultivation: 1) conventional soil tillage (CST) with cotton monoculture CSTCM; 2) CST with annual cottonsoybean-cotton succession (CSTCSC); 3) CST with cotton/ soybean/maize rotation (CSTCSM); and 4) cotton under a no-tillage system - NTS [soybean (spring-summer) + Urochloa ruziziensis (ruzigrass) (autumn-winter)/ maize intercropped with ruzigrass (spring-summer)/ cotton (spring-summer-autumn)]. CST treatments were fallow in autumn-winter (Table 2). The experiment was conducted using a randomized block design with four replications. The experimental plot for each cropping system covered an area of $576 \mathrm{~m}^{2}(14.4 \times 40 \mathrm{~m})$. Native vegetation (native Cerrado) without management interventions in a site adjacent to the experiment was used as a reference for exchangeable $\mathrm{K}$ and $\mathrm{OM}$ content in the soil profile.

\section{Tillage systems, crop management, and harvest}

Treatments with CST were prepared annually between late Sept and early Oct, after the beginning of the rainy season. The preparation consisted of a disc harrowing to turn the soil over up to $20 \mathrm{~cm}$ deep, followed by a leveling disc harrowing. Another leveling disc harrowing operation was performed two days before soybean, maize, or cotton sowing.

In Aug 2009, 2,000 $\mathrm{kg} \mathrm{ha}^{-1}$ of dolomitic limestone with $85 \%$ calcium carbonate equivalent was applied. In Oct 2009, before sowing the crops, $1,000 \mathrm{~kg} \mathrm{ha}^{-1}$ of phosphogypsum (PG) was added. In CST treatments, these additives were incorporated up to $20 \mathrm{~cm}$ with plowing and harrowing and were broadcasted on the soil surface without incorporation in the NTS treatment.

During the nine years of the experiment, soybean was sown in the spring, in the second half of Oct, after the beginning of the rainy season. Soybean row spacing was $45 \mathrm{~cm}$. Maize was sown between late Oct and early Nov also at $45-\mathrm{cm}$ row spacing. Cotton was sown from late Nov to mid-Dec, with $80 \mathrm{~cm}$ row spacing. Plant populations per ha ranged from 350,000 to $400,000,55,000$ to 65,000 , and 80,000 to 100,000 , for soybean, maize, and cotton, respectively, depending on the cultivar used each year. Cultivar, plant population,

Table 1 - Results of the soil analysis at 0-20 $\mathrm{cm}$ depth before initiating the experiment.

\begin{tabular}{|c|c|c|c|c|c|c|c|c|c|c|c|c|}
\hline $\mathrm{pH} \mathrm{CaCl}{ }_{2}$ & $\mathrm{P}^{1}$ & $\mathrm{~K}^{2}$ & $\mathrm{Ca}^{3}$ & $\mathrm{Mg}^{4}$ & $\mathrm{H}+\mathrm{Al}^{5}$ & $\mathrm{SB}^{6}$ & $\mathrm{CEC}^{7}$ & $\mathrm{~V}^{8}$ & SOM $^{9}$ & Clay & Silt & Sand \\
\hline & $\mathrm{mg} \mathrm{dm}^{-3}$ & & & $-\mathrm{cm}$ & $\mathrm{m}^{-3}$ & & & $\%$ & $\mathrm{~g} \mathrm{~kg}^{-1}$ & 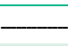 & $\mathrm{g} \mathrm{kg}^{-1}$ & \\
\hline 5.35 & 6.1 & 0.23 & 2.07 & 0.42 & 3.61 & 2.72 & 6.33 & 59 & 24.2 & 495 & 217 & 288 \\
\hline
\end{tabular}

${ }^{1}$ Available phosphorus; ${ }^{2}$ exchangeable potassium, extracted by Mehlich-1; ${ }^{3}$ calcium; ${ }^{4}$ magnesium, extracted by KCl 1 mol L-1; ${ }^{5}$ potential acidity, extracted by calcium acetate, $0.5 \mathrm{~mol} \mathrm{L-1}$, $\mathrm{pH} 7.0 ;{ }^{6}$ sum of exchangeable bases $=\mathrm{Ca}+\mathrm{Mg}+\mathrm{K} ;{ }^{7}$ cation exchange capacity $=\mathrm{H}+\mathrm{Al}+\mathrm{SB} ;{ }^{8}$ soil base saturation percentage $=\mathrm{SB} / \mathrm{CEC} \times$ $100,{ }^{9}$ soil organic matter by Walkley-Black method. Methodologies described in Teixeira et al. (2017).

Table 2 - Description of treatments of soil management, succession, and crop rotation systems over nine agricultural years.

\begin{tabular}{lcccc}
\hline & \multicolumn{3}{c}{ Treatments } \\
\cline { 2 - 4 } Agricultural year & CSTCM & Conventional soil tillage & No-tillage system \\
\cline { 2 - 4 } & Monoculture & CSTCSC & CSTCSM & RTS \\
\cline { 2 - 4 } $2005-2006$ & Cotton/fallow & Cotton/fallow & Cotton/fallow & Rotation and U. ruziziensis (ruzigrass) \\
$2006-2007$ & Cotton/fallow & Soybean/fallow & Soybean/fallow & Soybean / fuzallow \\
$2007-2008$ & Cotton/fallow & Cotton/fallow & Maize/fallow & Maize / ruzigrass \\
$2008-2009$ & Cotton/fallow & Soybean/fallow & Cotton/fallow & Cotton/fallow \\
$2009-2010$ & Cotton/fallow & Cotton/fallow & Soybean/fallow & Soybean / ruzigrass \\
$2010-2011$ & Cotton/fallow & Soybean/fallow & Maize/fallow & Maize / ruzigrass \\
$2011-2012$ & Cotton/fallow & Cotton/fallow & Cotton/fallow & Cotton/fallow \\
$2012-2013$ & Cotton/fallow & Soybean/fallow & Soybean/fallow & Soybean / ruzigrass \\
$2013-2014$ & Cotton/fallow & Cotton/fallow & Maize/fallow & Maize / ruzigrass
\end{tabular}


fertilization, and chemical control of pests, diseases, and weeds were standardized for each crop and within each agricultural year.

The mean annual fertilizations, in $\mathrm{kg} \mathrm{ha}^{-1}$ of $\mathrm{N}$, $\mathrm{P}_{2} \mathrm{O}_{5}$, and $\mathrm{K}_{2} \mathrm{O}$, were 111,126 , and 130 for cotton; 6, 54, and 46 for soybean; and 97, 119, and 137 for maize, respectively, adjusted based on the recommendations for these crops (Sousa and Lobato, 2004). All soybean fertilization was applied in the sowing furrow. Maize and cotton received all phosphate fertilizer and approximately $20 \%$ of $\mathrm{N}$ and $50 \%$ of $\mathrm{K}_{2} \mathrm{O}$ in the sowing furrow. The remaining $\mathrm{N}$ and $\mathrm{K}_{2} \mathrm{O}$ amounts were divided into two topdressing applications. The total amounts of fertilizers, in $\mathrm{kg} \mathrm{ha}^{-1}$ of $\mathrm{N}, \mathrm{P}_{2} \mathrm{O}_{5}$, and $\mathrm{K}_{2} \mathrm{O}$, were 999, 1,134 , and 1,170 in CSTCM treatment; 579, 846 and 834 in CSTCSC and 642, 897 and 939 in CSTCSM and NTS.

In the NTS treatment, after soybean harvest, ruzigrass was mechanically sown using $6 \mathrm{~kg} \mathrm{ha}^{-1}$ of seeds with $100 \%$ culture value. This operation occurred two days after desiccation of volunteer soybean plants and weeds in the plots using the paraquat herbicide (400 $\mathrm{g} \mathrm{ha}^{-1}$ of active ingredient). Maize in the NTS was intercropped with ruzigrass using $7 \mathrm{~kg} \mathrm{ha}^{-1}$ of seeds with $85 \%$ culture value mixed with the starter fertilizer distributed in the sowing furrows. Ruzigrass remained in the plots as a cover plant throughout the off-season after soybean or maize and was desiccated with glyphosate $\left(1,400 \mathrm{~g} \mathrm{ha}^{-1}\right.$ of active ingredient) 30 days before sowing the next maize or cotton crop.

Cotton, maize, and soybean crops were manually harvested in each experimental plot, at three random points, each including four rows 5-m long. Yield was obtained by adding the data collected at the three points and the results were converted into $\mathrm{kg} \mathrm{ha}^{-1}$ and grain moisture corrected to $13 \%$.

The accumulated export of $\mathrm{K}$ in each production system was determined by multiplying crop yields by the mean removal rates, equivalent to 17,20 , and 3.7 $\mathrm{kg}$ of $\mathrm{K}_{2} \mathrm{O}$ per ton of seed cotton, soybean, and maize grains, respectively (Borin et al., 2019; Duarte et al., 2019; Embrapa, 2013). From exported quantities, partial balances of K (Resende et al., 2019) were estimated, as well as the exported/applied ratios of the $\mathrm{K}$ fertilizer used in the period.

\section{Soil sampling and analysis}

In Oct 2014, soil samples were collected from the experimental plots and in the native Cerrado of an adjacent area, at the $0-5,6-10,11-20,21-30,31-60$, and 61$100 \mathrm{~cm}$ layers of the profile, to analyze the exchangeable $\mathrm{K}$ and soil organic matter (SOM) contents. At each depth, 10 soil samples were collected and homogenized to form a composite sample for the laboratory analysis. The exchangeable $\mathrm{K}$ was extracted with Mehlich-1 solution and quantified in a flame photometer, while SOM was determined by the Walkley-Black method (Teixeira et al., 2017).

\section{Statistical analysis}

The data at each sampling layer were submitted to the analysis of variance using SISVAR software (Statistical Analysis System, version 5.6) with means compared by the Tukey test. A $p \leq 0.05$ was used to indicate statistical significance.

\section{Results and Discussion}

\section{Exchangeable potassium and organic matter contents in the soil}

Although the exchangeable $\mathrm{K}$ contents were not statistically compared between the sampling depths, the highest absolute values were detected in the upper layers of the soil profile, mainly at $0-5 \mathrm{~cm}$, decreasing progressively with depth, irrespective of the treatment (Figure 1). Ferreira et al. (2009) also observed this tendency in a Rhodic Hapludox (Oxisol). The authors stated that reducing $\mathrm{K}$ levels in the profile are associated with a gradual lowering in organic carbon $(\mathrm{OC})$ contents and soil organic matter (SOM) to retain cations in deeper layers.

The SOM levels determined in the samples up to $100 \mathrm{~cm}$ in the profile (Figure 2) follow the same tendency as exchangeable $\mathrm{K}$ (Figure 1), indicating a strong relationship between these two variables. This behavior is expected for highly weathered soils, with low-activity clays, like the studied Oxisol, in which SOM accounts for most CEC (Lopes and Guilherme, 2016) and, therefore, for the retention of $\mathrm{K}$ in the soil profile.

The highest $\mathrm{K}$ content $\left(1.18 \mathrm{cmol}_{\mathrm{c}} \mathrm{dm}^{-3}\right)$ in NTS was found in the $0-5 \mathrm{~cm}$ layer (Figure 1) and was $79 \%$ higher than the mean value of the three CST treatments, consistent with the higher SOM content in this layer for NTS (Figure 2). Considering that the SOM and CEC are positively correlated in the Cerrado Oxisols (Lopes and Guilherme, 2016; Ramos et al., 2018), it seems that the increased CEC enhances the $\mathrm{K}$ retention and accumulation. The absence of soil tillage for nine years, straw production and abundant root development of $U$. ruziziensis (ruzigrass) used as a cover plant (Sanches et al., 2020), along with cotton, maize, and soybean crop residues in the NTS treatment, certainly had a positive influence on SOM accumulation and, consequently, on $\mathrm{K}$ levels in the $0-5 \mathrm{~cm}$ layer. The average annual of straw available in NTS for soybean sowing was 3,945 $\mathrm{kg} \mathrm{ha}{ }^{-1}$, from cotton crop residues; for corn sowing, $9,137 \mathrm{~kg} \mathrm{ha}^{-1}$ of the ruzigrass straw; and for cotton sowing, $11,388 \mathrm{~kg} \mathrm{ha}^{-1}$ of the maize crop residues and ruzigrass straw.

The production system and history of $\mathrm{K}$ fertilization influenced the $\mathrm{K}$ dynamics in soil profile. In the upmost surface layer, the exchangeable $\mathrm{K}$ content was $66 \%$ higher in NTS compared to CSTCM. However, in the deeper sampling layer, the situation was reversed with CSTCM presenting more than twice the $\mathrm{K}$ content 


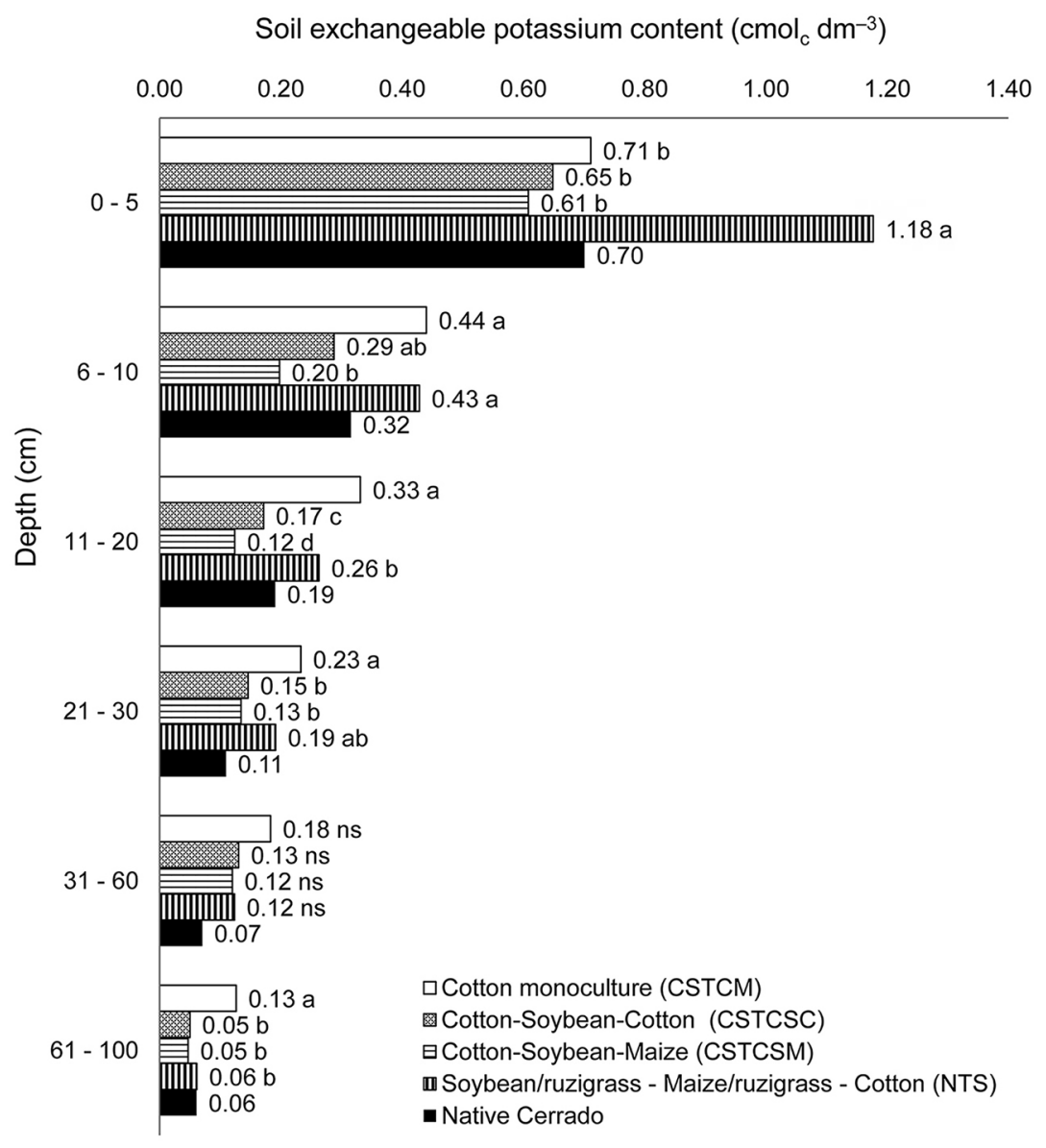

Figure 1 - Exchangeable $\mathrm{K}$ content in clayey Oxisol up to $100 \mathrm{~cm}$ depth after nine harvests in different cotton production systems. Within each depth, means that are followed by the same letter do not differ significantly (Tukey test; $p \leq 0.05$ ). ns $=$ not significant $(p>0.05)$ by $F$ test. Native Cerrado as reference of the natural condition.

(Figure 1). The comparison between the CSTCSM and NTS treatments, which received the same commercial crops and fertilizer amounts, shows that in the latter, the $\mathrm{K}$ content in the $0-5,6-10$, and $11-20 \mathrm{~cm}$ layers, was $93 \%, 115 \%$, and $117 \%$ higher, respectively. At depths 21-30, 31-60, and 61-100, the $\mathrm{K}$ levels were statistically similar between the CSTCSC, CSTCSM, and NTS treatments. These results reflect the role of SOM in increasing the net negative charge of the soil that can retain more cations in the top layers of the NTS (Ramos et al., 2018), as well as the active recovery of $\mathrm{K}$ by the ruzigrass root system from the deep layers to topsoil (Tanaka et al., 2019).

The weighted average of the sample layers up to $20 \mathrm{~cm}$ shows that the exchangeable $\mathrm{K}$ corresponded to $0.53 \mathrm{cmol}_{\mathrm{c}} \mathrm{dm}^{-3}$ in the NTS, equivalent to $829 \mathrm{~kg} \mathrm{ha}^{-1}$ of potassium chloride fertilizer $(\mathrm{KCl})$, and to $0.26 \mathrm{cmol}_{\mathrm{c}}$ $\mathrm{dm}^{-3}$ in CSTCSM (407 $\mathrm{kg} \mathrm{ha}^{-1}$ of $\mathrm{KCl}$ ). The conservationist management system with crop rotation under no-tillage and the inclusion of ruzigrass as a cover plant in the off-season retained more than twice the $\mathrm{K}$ available for absorption in the soil layer with greater root activity of the commercial crops, equivalent to about $422 \mathrm{~kg} \mathrm{ha}^{-1}$ of additional $\mathrm{KCl}$. This contrasting dynamics reinforces the importance of the no-till farming to prevent nutrient losses to runoff (Almeida et al., 2021), besides the strong influence of covering the soil by living plants as much as possible throughout the year to keep $\mathrm{K}$ recycling and its accessibility to plants in the crop system (Resende et al., 2019). The joint effect of no-till and ruzigrass activity composes an effective way to improve the use efficiency of $\mathrm{K}$ fertilizer in tropical soils.

Although not statistically compared, the reference soil from the native Cerrado area that had never been fertilized presented exchangeable $\mathrm{K}$ levels similar to those found in some production systems with annual crops at different depths (Figure 1). This shows that the clayey soil with a relatively high SOM content in that area (Figure 2) has a natural $\mathrm{K}$ reserve that is possibly kept due to the action of native vegetation roots distributed at great depths, promoting efficient recycling over time. 


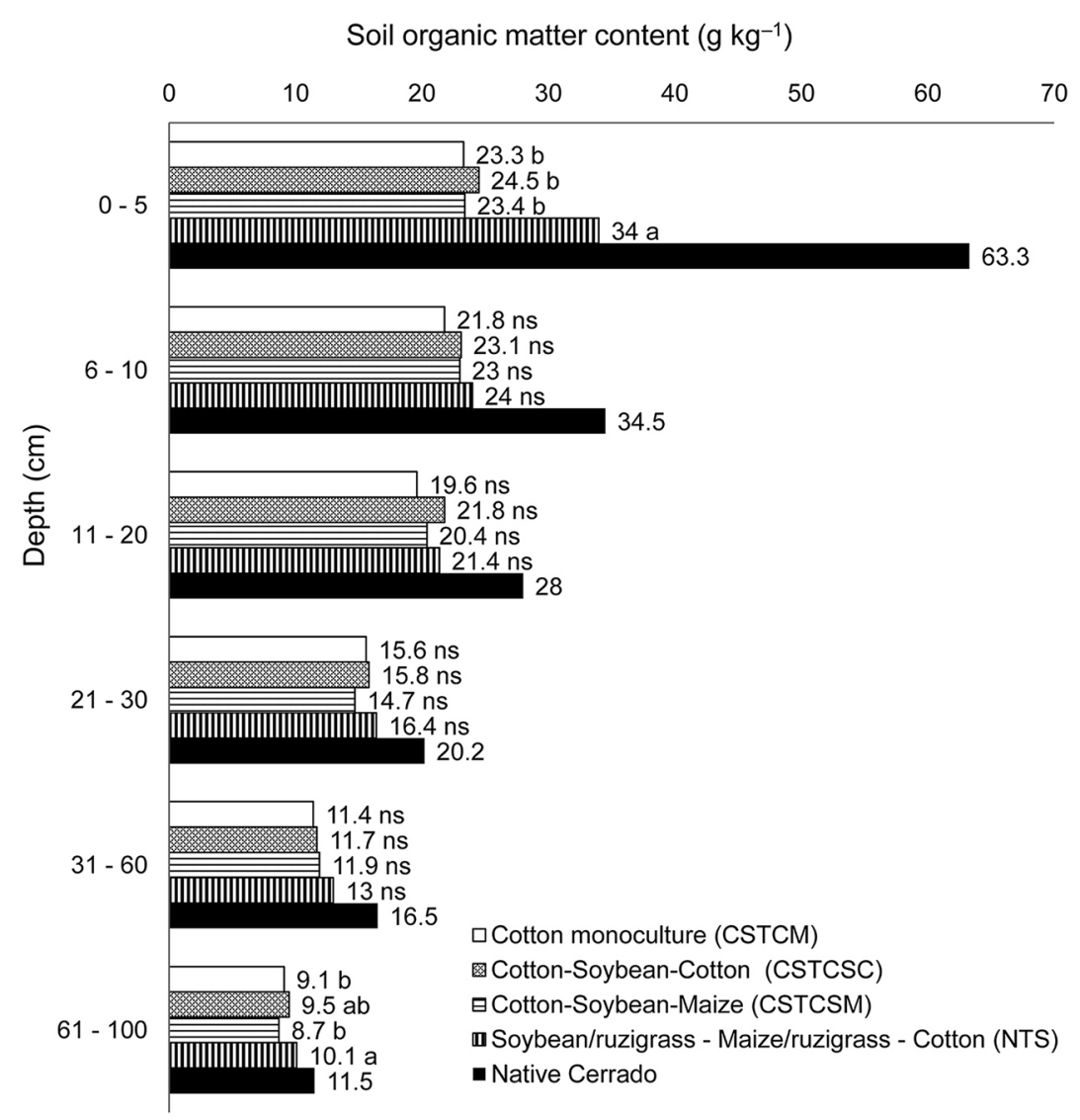

Figure 2 - Organic matter content in clayey Oxisol up to $100 \mathrm{~cm}$ depth after nine harvests in different cotton production systems. Within each depth, means followed by the same letter do not differ significantly (Tukey test; $p \leq 0.05$ ). ns = not significant $(p>0.05)$ by $\mathrm{F}$ test. Native Cerrado as reference of the natural condition.

\section{Partial potassium balance and exchangeable potassium pool in the soil profile}

The highest exchangeable $\mathrm{K}$ levels in the deeper sampling layer were observed in the CSTCM treatment (Figure 1). This treatment received the greatest cumulative dose of the nutrient over the nine years of the experiment (Figure $3 \mathrm{~A})$, which, associated with recurrent monocrop, plowing and harrowing, must have led to $\mathrm{K}$ mobilization to the deeper layers of the soil profile. Below $60 \mathrm{~cm}$, the volume and specific surface area of cotton roots are much smaller (Carmi et al., 1993), restricting their capacity to absorb nutrients. This low absorption possibly increases $\mathrm{K}$ loss from the system due to leaching out of the root exploration zone.

The equivalent amounts of $\mathrm{K}_{2} \mathrm{O}$ stored up to 100 $\mathrm{cm}$ deep were estimated for the treatments, assuming a soil bulk density equal to $1.0 \mathrm{~kg} \mathrm{dm}^{-3}$ over the entire sampling profile. The native Cerrado soil condition had $\pm 591 \mathrm{~kg} \mathrm{ha}^{-1}$ of $\mathrm{K}_{2} \mathrm{O}$ equivalent in exchangeable form, which reflects a stabilized state mainly because of biological recycling. Therefore, the anthropic use of soils with cultivation for many years before the experiment must have changed this equilibrium. Nevertheless, the pool of exchangeable $\mathrm{K}$ that built up after nine years of fertilization in different production systems (Figure 3A) indicates that the cultivated Oxisol can retain, at least temporarily, a higher amount of $\mathrm{K}$ in the profile than the existing amount in the original environment.

Soil acidity control practices, such as liming and PG amending, may promote an increase in CEC in soils with predominance of variable charges, as observed by Fageria et al. (2014), enhancing the potential for $\mathrm{K}$ retention by negative colloidal charges. However, the effects of different management systems on the dynamics and storage of the $\mathrm{K}$ provided in fertilizations were evident (Figures 3A and 3B).

The CSTCM and NTS treatments had the highest content of exchangeable $\mathrm{K}$ in the soil after nine years (Figure 3A); however, its distribution in the profile (Figure 3B) indicates a different behavior between these treatments. In CSTCM, almost half of the $\mathrm{K}$ detected was in the layer below $30 \mathrm{~cm}$ depth, indicating likelihood for leaching. In the NTS, a proportion of almost $70 \%$ remained in the topsoil layer (up to $30 \mathrm{~cm}$ ), showing that this system conditioned a more conservative environment for the $\mathrm{K}$ 
supplied in fertilization. Furthermore, its retention in a position in the profile with greater presence and activity of commercial crops roots can improve the $\mathrm{K}$ use efficiency.

An important differential in the NTS was the inclusion of ruzigrass intercropped with maize and as subsequent crop to soybean, acting as a cover plant and improving $\mathrm{K}$ cycling in the system. According to Ferreira et al. (2018), the use of Poaceae species as cover crops (including ruzigrass) after the soybean harvest increases biomass production, providing soil protection and straw for subsequent cotton cultivation under no-till in the Cerrado region. Oliveira et al. (2019) reported that maize intercropped with Urochloa brizantha produces a high amount of plant residues, in addition to nutrient cycling, including K. The same authors reported that plant biomass of $U$. brizantha or ruzigrass accumulated $\mathrm{K}$ similarly to or more than maize.

When compared to annual crops in general, Urochloa species develop a root system that penetrates deeper into the soil, with a large volume of roots, enabling high $\mathrm{K}$ absorption (Rosolem et al., 2019), including the non-exchangeable forms (Volf et al., 2018). According to Römheld and Kirkby (2010), K is transported mainly by diffusion from the soil to the root surface and the presence of hairs is crucial in absorption, as it increases the surface area of the root cylinder and the concentration gradient that triggers the $\mathrm{K}$ influx.

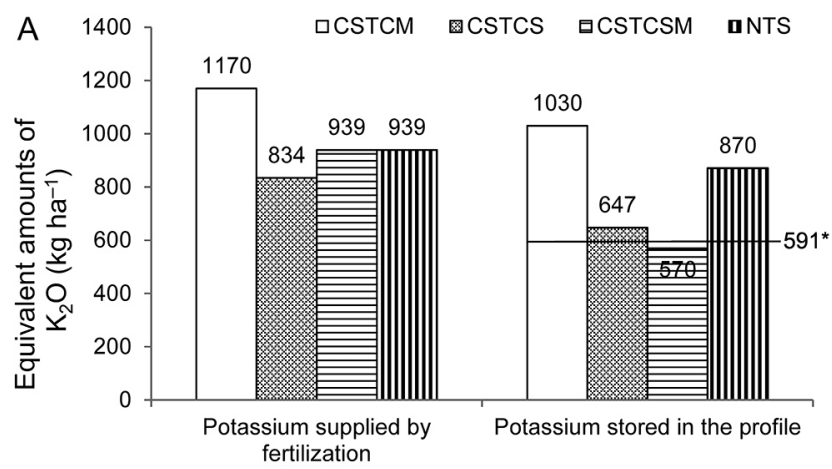

After successive harvests along nine cropping seasons in different production systems, the total $\mathrm{K}$ export expressed as $\mathrm{K}_{2} \mathrm{O}$ equivalent was estimated at $553,587,454$, and $487 \mathrm{~kg} \mathrm{ha}^{-1}$ for total adding of $1,170,834,939$, and $939 \mathrm{~kg} \mathrm{ha}^{-1}$ of $\mathrm{K}_{2} \mathrm{O}$ via fertilization in the treatments CSTCM, CSTCSC, CSTCSM, and NTS, respectively. The partial balance between $\mathrm{K}$ input and output in the systems indicated surpluses and the exported/applied nutrient ratio corresponded to relatively low offtake rates, ranging from 47 to $70 \%$ (Table 3). Thus, $\mathrm{K}$ additions by fertilization surpassed the harvest removal in all production systems, especially CSTCM, in which the combined effects of CST, absence of crop rotation, and higher $\mathrm{K}$ fertilization resulted in proportionally greater leaching to subsurface layers (Figures 1 and 3B), despite the fine texture in the soil with $495 \mathrm{~g} \mathrm{~kg}^{-1}$ of clay. The fate of the fertilizer K can follow different paths, besides the crop uptake, including adsorption in exchangeable positions on colloids, conversion to non-exchangeable forms, and losses by runoff and leaching (Rosolem et al., 2019). As the Oxisol is typically well drained and the experiment was installed in a field almost flat, greater importance of leaching can be expected in the potential K losses. According to Moterle et al. (2019), when K fertilization generates a positive balance that exceeds the soil buffering capacity, the presence of higher

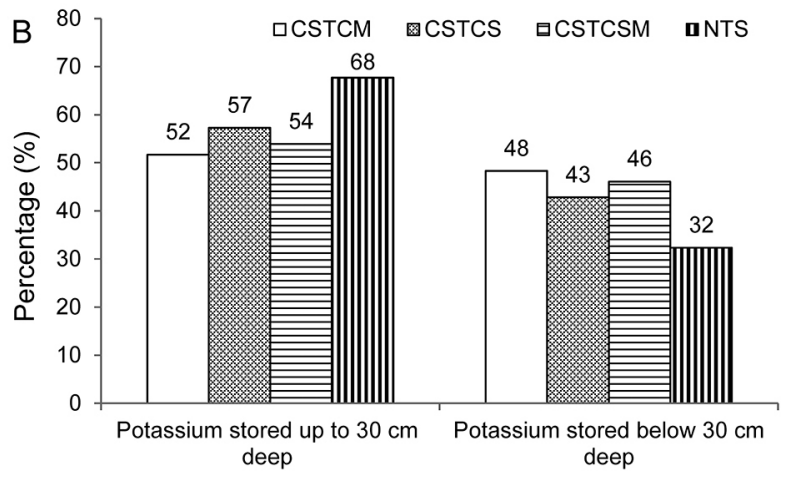

Figure 3 - Equivalent amounts of $\mathrm{K}_{2} \mathrm{O}$ cumulatively supplied by fertilization and stored up to $100 \mathrm{~cm}$ depth in the soil profile (A) and proportions of exchangeable $\mathrm{K}$ retained in the upper and deeper layers (B) of clayey Oxisol, after nine harvests in different cotton production systems. ${ }^{*}$ Stock in the soil under native Cerrado vegetation.

Table 3 - Cumulative crop production (PROD), $\mathrm{K}_{2} \mathrm{O}$ equivalent export (EXP) and partial balance, and offtake rate from $\mathrm{K}$ fertilization, after nine harvests in different cotton production systems.

\begin{tabular}{|c|c|c|c|c|c|c|c|c|c|}
\hline \multirow{2}{*}{ Systems } & \multicolumn{2}{|c|}{ Seed cotton } & \multicolumn{2}{|c|}{ Soybean } & \multicolumn{2}{|c|}{ Maize } & \multirow{2}{*}{ Total $\mathrm{K}_{2} \mathrm{O}$ EXP } & \multirow{2}{*}{$\mathrm{K}_{2} \mathrm{O}$ partial balance ${ }^{1}$} & \multirow{2}{*}{ Offtake rate ${ }^{2}$} \\
\hline & PROD & EXP & PROD & EXP & PROD & EXP & & & \\
\hline & & & & & $\mathrm{g} \mathrm{ha}^{-1}$ & & & & $\%$ \\
\hline CSTCM $^{3}$ & 32,536 & 553 & & - & - & - & 553 & 617 & 47 \\
\hline CSTCSC $^{4}$ & 19,251 & 327 & 12,980 & 260 & - & - & 587 & 247 & 70 \\
\hline CSTCSM $^{5}$ & 9,850 & 167 & 9,711 & 194 & 25,220 & 93 & 454 & 485 & 48 \\
\hline NTS 6 & 11,635 & 198 & 9,898 & 198 & 24,527 & 91 & 487 & 452 & 52 \\
\hline
\end{tabular}

${ }^{1}$ Difference between the equivalent amounts of $\mathrm{K}_{2} \mathrm{O}$ applied in fertilization and exported in harvests; ${ }^{2}$ Ratio between $\mathrm{K}$ export and fertilization; ${ }^{3}$ Conventional soil tillage (CST) with cotton monoculture; ${ }^{4} \mathrm{CST}$ with annual cotton-soybean-cotton succession; ${ }^{5} \mathrm{CST}$ with cotton/soybean/maize rotation; ${ }^{6}$ no-tillage system with cotton/ soybean/maize rotation and ruzigrass as a cover crop. 
exchangeable $\mathrm{K}$ levels increases leaching. Thus, once a sufficiency level for a given soil type is established, fertilizer recommendations closer to the crop needs are desirable, in amounts equivalent to $\mathrm{K}$ export in the harvested products, which minimizes translocation down the profile and eventual $\mathrm{K}$ losses outside the root zone (Kaminski et al., 2010).

Before the experiment beginning, the exchangeable $\mathrm{K}$ content was $0.23 \mathrm{cmol}_{\mathrm{c}} \mathrm{dm}^{-3}$ in the $0-20 \mathrm{~cm}$ layer, equivalent to $216 \mathrm{~kg} \mathrm{ha}^{-1}$ of $\mathrm{K}_{2} \mathrm{O}$ when assuming a soil bulk density of $1.0 \mathrm{~kg} \mathrm{dm}^{-3}$. After nine years under the NTS treatment, subtracting this initial reserve, the estimated stock for the same layer corresponded to $63 \%$ of the surplus of $452 \mathrm{~kg} \mathrm{ha}^{-1}$ of $\mathrm{K}_{2} \mathrm{O}$ calculated in the balance (Table 3). Among the CST treatments, calculations revealed that the maximum percentage retained up to $20 \mathrm{~cm}$ was $34 \%$ of the surplus from fertilization. Therefore, in addition to making the soil prone to lose $\mathrm{K}$ through erosive processes, the frequent tillage limits SOM accumulation, favoring a disruption in the $\mathrm{K}$ storage capacity in the topsoil. There is a weak $\mathrm{K}$ retention strength in highly weathered soils, such the Cerrado Oxisols, as result of the low frequency of 2:1 clay minerals to generate negative charges and adsorb cations, besides the competition with $\mathrm{Ca}$ and $\mathrm{Mg}$ derived from liming on adsorption to colloids (Moterle et al., 2019; Rosolem et al., 2019). These conditions make the $\mathrm{K}$ surplus from fertilization more susceptible to leaching.

The mean cotton yields were $3,615,3,855,3,285$, and $3,885 \mathrm{~kg} \mathrm{ha}^{-1}$ in CSTCM, CSTCSC, CSTCSM, and NTS treatments, respectively. Therefore, the NTS used in the present study is recommended. The NTS sustainability is supported by more efficient retention and storage of surplus $\mathrm{K}$ supplied in fertilization, keeping it cycling and more concentrated in the profile surface within the reach of crop roots, providing higher cotton yield potential.

In the NTS treatment, the combination of cotton, soybean, and maize rotation and ruzigrass as a cover plant, each with different characteristics of root and shoot development, productive potential, and life cycles, provided better soil use and $\mathrm{K}$ uptake from fertilization. The inclusion of ruzigrass in this no-tillage system promoted deep $\mathrm{K}$ recovery in the profile and its maintenance in circulation in the soilplant compartments, by increasing SOM (Santos et al., 2014), with consequent improvement in soil K buffering capacity. Thus, this grass sustained $\mathrm{K}$ availability in the upper layer, where it was retained due to the CEC from higher SOM, reducing losses by leaching.

After absorption, $\mathrm{K}$ is stored in the cytoplasm and vacuole and does not integrate any structural component of the plant cell. With the death of plant tissue and presence of enough moisture, the $\mathrm{K}$ contained in plant residues is quickly released into the soil solution (Lupwayi et al., 2006; Rosolem et al., 2019), contributing to nutrition of the subsequent crop. These aspects reinforce the premise that systems with the presence of live plants for a longer time throughout the year are more efficient in keeping $\mathrm{K}$ availability and minimizing losses.

In all production systems, $\mathrm{K}$ export was lower than the amount supplied by fertilization, generating a surplus in the nutrient balance (Table 3), which increased soil $\mathrm{K}$ availability in the $0-20 \mathrm{~cm}$ layer to values above the critical level of $0.13 \mathrm{cmol}_{\mathrm{c}} \mathrm{dm}^{-3}$ (Sousa and Lobato, 2004). In these situations, especially in modalities similar to the NTS used in this study, there is an opportunity to adjust fertilization in cotton cropping systems to reduce production costs and increase the use efficiency of $\mathrm{K}$ fertilizer.

\section{Conclusions}

Conventional tillage in clayey Oxisol with cotton monoculture favors the leaching of $\mathrm{K}$ surplus from fertilization. Conversely, no-tillage system with cotton / soybean / maize rotation and the inclusion of ruzigrass as a cover plant allows better control of the $\mathrm{K}$ dynamics, keeping it in circulation in the root zone and reducing losses by leaching. Increased OM in this system enlarges the $\mathrm{K}$ storage capacity in the topsoil. The adoption of no-tillage crop systems integrating grass species, such as Urochloa ruziziensis, is a viable way to improve the use efficiency of $\mathrm{K}$ fertilizers for cotton cultivation in highly weathered tropical soils.

\section{Acknowledgments}

The authors thank the Goiás Foundation (Fundação Goiás) for the operational support and for providing the experimental area for conducting the experiment and thank Brazilian Agricultural Research Corporation (Embrapa) and the Goiás Cotton Crop Incentive Fund (Fialgo) for partially funding the studies.

\section{Authors' Contributions}

Conceptualization: Ferreira, A.C.B.; Borin, A.L.D.C.; Lamas, F.M. Data acquisition: Ferreira, A.C.B.; Borin, A.L.D.C. Data analysis: Ferreira, A.C.B.; Borin, A.L.D.C.; Ferreira, G.B.; Resende, A.V. Design of methodology: Ferreira, A.C.B.; Borin, A.L.D.C.; Lamas, F.M.; Resende, A.V. Writing and editing: Ferreira, A.C.B.; Borin, A.L.D.C.; Resende, A.V.

\section{References}

Almeida, T.F.; Carvalho, J.K.; Reid, E.; Martins, A.P.; Bissani, C.A.; Bortoluzzi, E.C.; Brunetto, G.; Anghinoni, I.; Carvalho, P.C.F.; Tiecher, T. 2021. Forms and balance of soil potassium from a long-term integrated crop-livestock system in a subtropical Oxisol. Soil and Tillage Research 207: e104864.

Alvares, C.A.; Stape, J.L.; Sentelhas, P.C.; Gonçalves, J.L.M.; Sparovek, G. 2013. Köppen's climate classification map for Brazil. Meteorologische Zeitschrift 22: 711-728. 
Boldrin, P.F.; Souto, H.F.; Salles, L.S.; Furtini Neto, A.E. 2019. Alternative sources of potassium for maize cultivation. Ciência e Agrotecnologia 43: e023619.

Borin, A.L.D.C.; Ferreira, G.B.; Carvalho, M.C.S.; Ferreira, A.C.B. 2019. Cotton nutrition and fertilization in the Cerrado region $=$ Nutrição e adubação do algodão na região do Cerrado. p. 283-323. In: Flores, R.A.; Cunha, P.P.; Marchão, R.L.; Moraes, M.F., eds. Nutrition and fertilization: of large crops in the cerrado region $=$ Nutrição e adubação: de grandes culturas na região do cerrado. Gráfica UFG, Goiânia, GO, Brazil (in Portuguese).

Carmi, A.; Plaut, Z.; Sinai, M. 1993. Cotton root growth as affected by changes in soil water distribution and their impact on plant tolerance to drought. Irrigation Science 13: 177-182.

Companhia Nacional de Abastecimento [CONAB]. 2020. Agricultural information - crops. Cotton: Historical series = Informações agropecuárias - safras. algodão: série histórica. $\mathrm{CONAB}$, Brasília, DF, Brazil. Available at: https://www.conab.gov.br/info-agro/safras/ serie-historica-das-safras [Accessed May 26, 2020] (in Portuguese)

Duarte, A.P.; Abreu, M.F.; Francisco, E.A.B.; Gitti, D.C.; Barth, G.; Kappes, C. 2019. Reference values of grain nutrient content and removal for corn. Revista Brasileira de Ciência do Solo 43: e0180102.

Empresa Brasileira de Pesquisa Agropecuária [EMBRAPA]. 2013. Soybean production technologies - Central Brazil $2014=$ Tecnologias de produção de soja: Região Central do Brasil 2014. Embrapa Soja, Londrina, PR, Brasil (in Portuguese).

Fageria, N.K.; Moreira, A.; Moraes, L.A.C.; Moraes, M.F. 2014. Influence of lime and gypsum on yield and yield components of soybean and changes in soil chemical properties. Communications in Soil Science and Plant Analysis 45: 271-283.

Ferreira, A.C.B.; Borin, A.L.D.C.; Bogiani, J.C.; Lamas, F.M. 2018. Suppressive effects on weeds and dry matter yields of cover crops. Pesquisa Agropecuária Brasileira 53: 566-574.

Ferreira, E.V.O.; Anghinoni, I.; Carvalho, P.C.F.; Costa, S.E.V.G.A.; Cao, E.G. 2009. Soil potassium content in an integrated croplivestock system under no-tillage with different grazing intensities. Revista Brasileira de Ciência do Solo 33: 1675-1684 (in Portuguese, with abstract in English).

Food and Agriculture Organization of the United Nations [FAO]. 2020. World Food and Agriculture - Statistical pocketbook 2020. FAO, Rome, Italy. Available at: http://www.fao.org/3/cb1329en/ CB1329EN.pdf [Accessed Feb 01, 2021]

Garcia, R.A.; Crusciol, C.A.C.; Calonego, J.C.; Rosolem, C.A. 2008. Potassium cycling in a corn-brachiaria cropping system. European Journal of Agronomy 28: 579-585.

Kaminski, J.; Moterle, D.F.; Rheinheimer, D.S.; Gatiboni, L.C.; Brunetto, C. 2010. Potassium availability in a Hapludalf soil under long term fertilization. Revista Brasileira de Ciência do Solo 34: 783791.

Lopes, A.S.; Guilherme, L.S.G. 2016. A career perspective on soil management in the cerrado region of Brazil. Advances in Agronomy 137: 1-72.

Lupwayi, N.Z.; Clayton, G.W.; O'Donovan, J.T.; Harker, K.N.; Turkington, T.K.; Soon, Y.K. 2006. Potassium release during decomposition of crop residues under conventional and zero tillage. Canadian Journal of Soil Science 86: 473-481.

Moterle, D.F.; Bortoluzzi, E.C.; Kaminsk, J.; Rheinheimer, D.S.; Caner, L. 2019. Does Ferralsol clay mineralogy maintain potassium long- term supply to plants? Revista Brasileira de Ciência do Solo 43: e0180166.

Oliveira, S.M.; Almeida, R.E.M.; Pierozan Junior, C.; Reis, A.F.B.; Souza L.F.N.; Favarin, J.L. 2019. Contribution of corn intercropped with Brachiaria species to nutrient cycling. Pesquisa Agropecuária Tropical 49: e55018.

Ramos, F.T.; Dores, E.F.G.C.; Weber, O.L.S.; Beber, D.C.; Campelo Junior, J.H.; Maia, J.C.S. 2018. Soil organic matter doubles the cation exchange capacity of tropical soil under no till farming in Brazil. Journal of the Science of Food and Agriculture 98: 35953602.

Resende, A.V.; Borghi, E.; Gontijo Neto, M.M.; Fontoura, S.M.V.; Borin, A.L.D.C.; Oliveira, A.J.; Carvalho, M.C.S.; Kappes, C. 2019. Nutrient balance and fertilization management in soil with improved fertility $=$ Balanço de nutrientes e manejo da adubação em solos de fertilidade construída. Tópicos em Ciência do Solo 10: 342-398 (in Portuguese).

Römheld, V.; Kirkby, E.A. 2010. Research on potassium in agriculture: needs and prospects. Plant and Soil 335: 155-180.

Rosolem, C.A.; Crusciol, C.A.C.; Volf, M.R.; Nascimento, C.A.C.; Mariano, E. 2019. Potassium dynamics in the soil-plant system = Dinâmica do potássio no sistema solo-planta. Tópicos em Ciência do Solo 10: 283-341 (in Portuguese).

Sanches, I.R.; Lazarini, E.; Pechoto, E.A.P.; Santos, F.L.; Bossolani, J.W.; Parra, L.F.; Meneghette, H.H.A. 2020. Maize second-crop intercropped with forages and soil correction depths: grain yield and forages root distribution. Research, Society and Development 9: e798974778.

Santos, H.G.; Jacomine, P.K.T.; Anjos, L.H.C.; Oliveira, V.A.; Lumbreras, J.F.; Coelho, M.R.; Almeida, J.A.; Cunha, T.J.F.; Oliveira, J.B. 2013. Brazilian Soil Classification System = Sistema Brasileiro de Classificação de Solos. 3ed. Embrapa, Brasília, DF, Brazil (in Portuguese).

Santos, I.L.D.; Caixeta, C.F.; Sousa, A.A.T.C.D.; Figueiredo, C.C.D.; Ramos, M.L.G.; Carvalho, A.M.D. 2014. Cover plants and mineral nitrogen: effects on organic matter fractions in an oxisol under no-tillage in the cerrado. Revista Brasileira de Ciência do Solo 38: 1874-1881.

Soil Survey Staff. 2014. Keys to Soil Taxonomy. 12ed. USDA-Natural Resources Conservation Service, Washington, DC, USA.

Sousa, D.M.G.; Lobato, E. 2004. Cerrado: Soil Correction and Fertilization = Cerrado: Correção do Solo e Adubação. 2ed. Embrapa Cerrados, Planaltina, DF, Brazil (in Portuguese).

Tanaka, K.S.; Crusciol, C.A.C.; Soratto, R.P.; Momesso, L.; Costa, C.H.M.; Franzluebbers, A.J.; Oliveira Junior, A.; Calonego, J.C. 2019. Nutrients released by Urochloa cover crops prior to soybean. Nutrient Cycling in Agroecosystems 113: 267-281.

Teixeira, P.C.; Donagemma, G.K.; Fontana, A.; Teixeira, W.G. 2017. Manual of Soil Analysis Methods = Manual de Métodos de Análise de Solo. 3ed. Embrapa, Brasília, DF, Brazil (in Portuguese).

Volf, M.R.; Guimarães, T.M.; Scudeletti, D.; Cruz, I.V.; Rosolem, C.A. 2018. Potassium dynamics in ruzigrass rhizosphere. Revista Brasileira de Ciência do Solo 42: e0170370.

Yang, J.S.; Hu, W.; ZhaO, W.; Meng, Y.; Chen, B.; Wang, Y.; Zhou, Z. 2016. Soil potassium deficiency reduces cotton fiber strength by accelerating and shortening fiber development. Scientific Reports 6: 28856. 